\section{How to get your article published as a JME feature article and why they matter for the field}

\author{
Jennifer Blumenthal-Barby
}

I published my first article in the Journal of Medical Ethics back in 2007 as an (almost) newly minted $\mathrm{PhD}$. It was a proud moment. I respected the JME as a journal where I had read some of the most tightly argued and challenging essays in the literature. They inspired me to specialise in medical ethics and rethink some of my fundamental positions on various topics. This has been the case since, and I am proud now to join the editorial team as an associate editor focusing on increasing North American presence and on the journal's feature articles.

FEATURE ARTICLES: FACTS AND FIGURES

The journal has included feature articles for several years now, and because they have worked so well, the editorial team wants to build on and invest in their success. Feature articles are primarily selected from the best extended essays or research papers. They are among the most highly cited and accessed articles in the field. On average, they have twice as many citations as a regular article published in the journal (and five times as many citations as an article in Ethics, a top philosophy journal). This may be due, in part, to the journal's practice of making feature articles open access so that all scholars can access them. In addition, the JME is committed to helping promote these articles and their commentaries on its online and social media platforms (eg, an active blog, an online first page updated with new articles daily and a Twitter account with over $12 \mathrm{~K}$ followers). JME articles have an average of 24 mentions with a range of $0-1036$. This helps authors extend the reach of their scholarship and increase the likelihood of it making an impact where it matters. This leads to the second point I want to comment on: what the editorial team looks for in feature articles.

Correspondence to Dr Jennifer Blumenthal-Barby, Center for Medical Ethics and Health Policy, Baylor College of Medicine, Houston, TX 77006, USA; Jennifer.blumenthal-barby@bcm.edu

\section{VISION AND SELECTION CRITERIA FOR FEATURE ARTICLES: REPRESENTING THE BEST OF BIOETHICS}

Our vision for feature articles is that they are of high significance and attempt to move the field forward. They are selected for one or more of the following reasons: they are very well-argued and of exceptional quality; they are novel in identifying a new or neglected issue; they focus on a timely, important or controversial topic; they address a particularly important issue for medical ethics head-on. Feature articles are poised to move or change policy, practice or thinking on a topic. They also well represent the journal's overall aims which are to prioritise succinct (under 3500 words; though we will also consider up to 7000 words), jargon-free, wellargued, clinically relevant articles. 'Wellargued' papers are those that promote reasoned discussion of moral issues, clarify or deepen discussion of moral issues, identify assumptions and test arguments and positions for their consistency with other positions, think ahead to future cases that might clash with principles employed in the argument and engage with morally controversial issues as needed. Publishing a paper as a feature article does not mean that the editorial team endorses the position of the paper or agrees with all of the arguments made. It simply means that the paper meets one or more of the above criteria.

For example, this month's issue features an article by Rosamond Rhodes on 'Why Not Common Morality'. ${ }^{1}$ Rhodes argues that the dominant common morality approach to medical ethics is insufficient and that medicine has its own (different) set of ethical norms, prohibitions and obligations that medical professionals should follow. The article is accompanied by commentaries by Tom Beauchamp, ${ }^{2}$ Alex London, ${ }^{3}$ Ruth Macklin, ${ }^{4}$ Laurence McCullough, ${ }^{5}$ Soren Holm, ${ }^{6}$ Charles Foster $^{7}$ and Bryanna Moore. ${ }^{8}$ These commentaries challenge, deepen and expand the discourse in the feature article.

Next month's feature article (already online) is coauthored by Julian Savulescu, Claudia Brick and Guy Kahane. The article, 'Worth Living or Worth Dying? The Views of the General Public About Allowing Disabled Children to Die, ${ }^{9}$ involves the first ever large survey study of the views of the general (UK) public about the benefit of life in hypothetical cases similar to real cases such as Charlie Gard and Alfie Evans. The authors then evaluate these views in comparison with existing ethical frameworks for decision-making. The article is accompanied by commentaries by Robert Truog, ${ }^{10}$ Seema Shah (with Ben Wilfond, Aaron Wightman, Doug Diekema and Erin Paquette) ${ }^{11}$ Monica Lemmon ${ }^{12}$ and Ryan Nelson. ${ }^{13}$ The article is an exemplar of how empirical ethics and normative ethics can inform each other.

Having your work published as a feature article is a badge of honour and an opportunity to have deep thinkers and scholars with expertise and experience in relevant areas engage with your work and help you move it forward.

\section{EXCITING NEW PLANS FOR FEATURE ARTICLES AND COMMENTARIES}

Each featured article is currently accompanied by a handful of short invited commentaries (500-1000 words) by scholars from a diverse range of perspectives, including senior leaders in the field. We aim to select commentaries that engage with the arguments in the feature article, rather than ones that use the commentary as a platform to highlight their own work of relevance to the topic under discussion. We prioritise commentaries that are succinct, well-argued, charitable in read and tone to the feature article under discussion (this in no way requires that they be uncritical, of course). We aim for diversity in commentators (eg, junior/senior, gender, home discipline such as philosophy/medicine/ law, geographic location and so on).

One new, exciting step the editorial team has decided to take is to open these up beyond invited commentaries, and select a small handful of proposed commentaries as well, such that each feature article will be accompanied by a mix of invited and proposed commentaries (approximately five in total). This will allow us to better increase our goals of (1) diversity in perspectives and (2) moving forward thinking, practice and policy on key bioethics issues. Interested authors will be asked to submit an abstract-length proposal through the journal's website. Feature articles will appear online with a link to submit a commentary proposal. This is an excellent opportunity to have a voice on some of the most important 


\section{Editorial}

issues and current debates in the field with a fairly low 'lift' (500-1000 words).

\section{SUBMITTING A FEATURE ARTICLE}

If you are interested in submitting your work and having it considered as a feature article, please read details, submit here and include an explanation in the cover letter about why your article is well-suited for a feature article. If you have ideas for feature articles, please feel free to contact me (Jennifer.blumenthal-barby@bcm. edu) or a member of the editorial team.

Funding The authors have not declared a specific grant for this research from any funding agency in the public, commercial or not-for-profit sectors.

Competing interests None declared.

Patient consent for publication Not required.

Provenance and peer review Not commissioned; internally peer reviewed.
(C) Author(s) (or their employer(s)) 2019. No commercial re-use. See rights and permissions. Published by BMJ.

\section{Check for updates}

To cite Blumenthal-Barby J. J Med Ethics 2019:45:755-756.

Received 6 November 2019

Accepted 13 November 2019

Published Online First 6 December 2019

J Med Ethics 2019;45:755-756.

doi:10.1136/medethics-2019-105944

\section{REFERENCES}

1 Rhodes R. Why not common morality? I Med Ethics 2019:45:770-7.

2 Beauchamp T. On Rhodes's failure to appreciate the connections between common morality theory and professional biomedical ethics. J Med Ethics 2019;45:791-2.

3 London AJ. Uncommon misconceptions and common morality. J Med Ethics 2019:45:778-9.

4 Macklin R. Common morality and medical ethics: not so different after all. J Med Ethics 2019;45:780-1.
5 McCullough LB. The ethical concept of medicine as a profession discovery or invention? J Med Ethics 2019;45:787-8

6 Holm S. Roles, professions and ethics: a tale of doctors, patients, butchers, bakers and candlestick makers. J Med Ethics 2019:45:782-3.

7 Foster C. Doctors should be morally common: a reply to Rosamond Rhodes. J Med Ethics 2019;45:784-6.

8 Moore B. Why only common morality? J Med Ethics 2019;45:789-90.

9 Brick C, Kahane G, Wilkinson D, et al. Worth living or worth dying? the views of the general public about allowing disabled children to die. J Med Ethics 2019. doi:10.1136/medethics-2019-105639.

10 Truog RD. Is 'best interests' the right standard in cases like that of Charlie Gard? J Med Ethics 2019. doi:10.1136/medethics-2019-105808.

11 Shah S, Wilfond BS, Wightman A, et al. Relationships help make life worth living. J Med Ethics 2019. doi:10.1136/medethics-2019-105809.

12 Lemmon M. Deciding when a life is not worth living: an imperative to measure what matters. J Med Ethics 2019. doi:10.1136/medethics-2019-105807.

13 Nelson RH. Public views about quality of life and treatment withdrawal in infants: limitations and directions for future research. J Med Ethics 2019. doi.10.1136/medethics-2019-105836. 